Please cite as: Thomann, Eva; Rapp, Carolin (2017): "Who Deserves Solidarity? Unequal Treatment of Immigrants in Swiss Welfare Policy Delivery”. Policy Studies Journal, online first: 1-22. DOI: 10.1111/psj.12225.

\title{
Who Deserves Solidarity? Unequal treatment of Immigrants in Swiss Welfare Policy Delivery
}

Pre-print version - online first version available at:

http://onlinelibrary.wiley.com/doi/10.1111/psj.12225/full

\section{Eva Thomann}

University of Exeter

Department of Politics

Office Amory A236b

Exeter EX4 4RJ

Devon, United Kingdom

e.thomann@exeter.ac.uk

\section{Carolin Rapp}

University of Southern Denmark

Department of Political Science and Public Management

Campusvej 55

DK-5230 Odense M

mail@carolinrapp.com

\begin{abstract}
Rising immigration rates in Western Europe concur with increasing anti-immigrant attitudes. While assessments of welfare eligibility in the United States demonstrably hinge on how public servants perceive different racial groups as deserving, we know less about ethnically motivated discrimination in the European context. This paper argues that Switzerland is a critical case for studying such developments. It combines social construction theory and the deservingness heuristic to analyze how social constructions of Swiss natives and immigrants influence 90 disability benefits insurance procedures. Findings reveal that immigrants are perceived as less deserving and less powerful than Swiss applicants. Thus, Swiss welfare workers do not allocate welfare benefits independently of an applicant's nationality. Our results raise fundamental questions about the equal treatment of welfare applicants in times of rising immigration and anti-immigrant attitudes. The feed-forward effects of social constructions imply longer-term consequences for good administrative practices and society that require scholarly attention.
\end{abstract}

Keywords: deservingness, discrimination, frontline implementation, immigrants, social construction of target groups, social equity, welfare chauvinism 


\section{Introduction}

This paper assesses how the social construction of immigrant and native applicants affects the frontline delivery of welfare policy in Switzerland. Recent developments in Western societies have demonstrated that increasing immigration rates fuel competition over scarce resources between the majority and immigrant population (van der Waal, de Koster and van Oorschot 2013). This has particular implications for welfare policies, which are, first and foremost, concerned with the question of "who gets what, when, and how" (Lasswell 2012). This article analyses how these issues translate into public action. In the discretionary practice of administrative welfare procedures, societal solidarity manifests itself through the concrete allocation of benefits and services for those seeking public assistance. Here, the judgments, decisions, and actions of frontline welfare workers become decisive (Brodkin 1997; Lipsky 1980; Meyers, Riccucci, and Lurie 2001). The equal treatment of clients is one of the basic principles of good administrative practice, representing the values of fairness and democratic accountability (Frederickson 1990). However, there is ample evidence that client characteristics generally play an influential role in the awarding of welfare benefits and services because "bureaucrats with discretion can act according to their own biases" (Einstein and Glick 2016, 2). The question arises whether presumably technical bureaucracies implement welfare policies independently of the applicant's nationality.

In this context, "the social construction of target populations has a powerful influence on public officials” (Schneider and Ingram 1993, 334). Stereotypes about the power and deservingness of target groups explain inequalities in both the distribution and allocation of benefits (Ingram, Schneider, and DeLeon 2007; Nicholson-Crotty and Nicholson-Crotty 2004; Pierce et al. 2014; Schneider and Ingram 1997; Schneider and Sidney 2009). Particularly in the context of the United States, racial bias in policy delivery is amply documented (DiAlto 2005; Einstein and 
Glick 2016; Epp et al. 2017; Frederickson 1990; Gooden 2006; Johnson 2012; Liang 2016; Maynard-Moody and Musheno 2012; Monnat 2010; Moynihan and Herd 2010; Piatak 2016; Schram, Soss, and Fording 2010; Yoo 2008). In contrast, much less is known about the role of nationality and race in welfare delivery in the European context. It has been argued that the different institutional-cultural contexts within which continental Western European welfare programs operate might even reverse discriminatory behavior (Terum et al. 2017). European welfare systems lack many of the institutional features that trigger discrimination in the United States (see Epp et al. 2017): they tend to redistribute income at larger scales and have more generous as well as less fragmented social programs that are less exclusively targeted at ethnic minorities. Caseworkers are more professionalized and better educated, they can typically make use of language interpretation services, and are often more sensitized to cultural issues (Smedley et al. 2002; Terum et al. 2017).

Despite these differences, it is premature to assume that racial or ethnic bias is not an issue in Western European bureaucracies. As Garand et al. (2017) show, rising immigration rates shift perceptions of welfare deservingness from questions of race to questions of nationality. The aforementioned developments highlight the salience of such issues for Western Europe. Taking care of the disabled and (incurably) ill lies at the core of every society's welfare policy. We generally tend to see the vulnerable as most deserving. Yet increasing levels of immigration also raise the belief that immigrants' main motivation is to take advantage of these benefits reserved for the truly needy. This challenges the majority’s overall solidarity with immigrants and leads to welfare chauvinism. Such preferences for more generous welfare entitlements for native citizens are driven by the way in which people perceive different societal groups as deserving (Boräng 2015; Jensen and Petersen 2016; Petersen et al. 2011; Petersen 2012; van Oorschot 2000; 2006). Against this background, cultural-institutional differences in welfare systems may not be able to mitigate biased decisions of welfare workers. 
As a result, disability insurances are often part of public and political debates concerning potential frauds and exploitations of this pension system which result in significant pressures on caseworkers. This also applies to the present case under study, namely the allocation of disability benefits in Switzerland in the period from 2003-2008. Switzerland is an early case for high immigration rates, rising anti-immigrant attitudes, and their mobilization through right-wing populist parties, taking place now, to varying degrees, all over Europe (Manatschal and Rapp 2015; Sager and Thomann 2016). Additionally, its cultural, linguistic, religious, and regional diversity make Switzerland a microcosm of Europe (Freitag and Rapp 2013, 440). Against this background, the paper addresses two crucial questions: What social constructions can we find in Swiss welfare delivery? And how do these social constructions affect the way in which welfare benefits are granted to applicants?

To this end, we overcome disciplinary boundaries and combine social construction theory with insights from public opinion, policy design, and implementation research to formulate concrete expectations about the welfare procedures of applicants from different origins. We make use of a unique data set comprising welfare case files of disability benefit procedures of 48 Swiss citizens and 42 immigrant applicants, which were coded based on in-depth content analyses of disability insurance case documentations (Bolliger et al. 2010). The results, based on cluster and regression analyses, reveal how social constructions of immigrants significantly shape the perceptions and decisions of the actors involved in these procedures. We conclude by discussing important implications for social equity in welfare delivery in times of rising antiimmigrant attitudes.

\section{The case of Swiss disability insurance}

Switzerland is a particularly interesting case to extend social equity research beyond the United 
States. While Switzerland shares the above-mentioned institutional features of Western European welfare systems, its welfare system is often considered to be closer to the US system than other continental European welfare regimes (Armingeon 2001). Disability benefits allocation in Switzerland is also a critical case for revealing the tension between solidarity for the needy and welfare chauvinism. Switzerland has continually had high levels of immigration and anti-immigrant attitudes, as expressed in the recent popular votes against immigrant rights (Freitag and Rapp 2013; Rapp 2015). Swiss disability benefit statistics further show that the risk of disability is, on average, higher for immigrants than for Swiss citizens (Bolliger et al. 2010). In the mid-2000s, these numbers fostered ongoing public debates on the alleged exploitation of the welfare state by migrants, political contestation, and immense media scrutiny on welfare agencies.

Swiss disability insurance defines disability as the continuing full or partial loss of the ability to take up employment due to impaired health resulting from illness or accident in spite of reasonable treatment and rehabilitation. The insurance uses rehabilitation measures or financial support to ensure the livelihoods of those who suffer from disabilities. It is eligible for everyone suffering from disability, regardless if caused by birth or by accident. Every person residing and working in Switzerland can apply for disability benefits, yet the largest target group are low-skilled manufactural workers. The approval of disability benefits relies on three points: First, an individual's risk of illness or accident; second, the (in)capacity to continue to work or to be reintegrated into work; and third, the outcome of the disability benefit procedure (Wyssmueller and Efionayi 2007). The procedure follows the principle of "rehabilitation before pension” - meaning that the primary goal is to improve the earning capacity of applicants. Cash benefits are only granted when all rehabilitation options have been exhausted.

In response to the above-mentioned concerns and austerity pressures, the Disability Insurance Act enacted tighter criteria to ensure that benefits are strictly awarded based, first and foremost, 
on purely medical criteria. If rehabilitation failed, the purpose of the procedure was to evaluate an objective "percentage" of incapacity to work. Obviously, the personal history (e.g., socioeconomic status, biographical stress factors) as well as individual attitudes and behavior (e.g., language skills, socio-cultural conceptions of health and illness, readiness to continue working, presentation of symptoms) shape the pathway towards disability. However, legally, the benefit decision had to be strictly dissociated from such non-disability (e.g. psychosocial) factors. Restrictive criteria, in particular, applied to health problems difficult to diagnose medically, such as somatoform pain disorders. As a result, disability insurance officials and medical advisors had to take tough decisions about the allocation of benefits. This political and legal context leads us to expect that prevailing perceptions of applicants of different nationalities have an observable influence on the benefit application procedures and their outcomes.

\section{Social constructions in welfare policy delivery}

Both experimental and field research suggests that persisting stereotypes, in terms of simplified cognitive representations of how members of a distinct group are similar or different from members of other groups, provoke discrimination of immigrants during service delivery, especially in interaction with gender (Brodkin 1993; Einstein and Glick 2016; Fineman 1998; Gooden 2006; Grohs, Adam, and Knill 2016; Johnson 2012; Liang 2016; Lipsky 1980; Monnat 2010; Moynihan and Herd 2010; Nicholson-Crotty and Nicholson-Crotty, 2004; Piatak, 2015; Schram, Soss, and Fording 2010; Watkin-Hayes 2009). Normative individual assessments of deservingness become particularly salient when welfare agents need to cope with austerity pressures that force them to prioritize some clients over others (Maynard-Moody and Musheno 2012; Tummers et al. 2015). Political economists have proposed several theoretical explanations. For example, taste-based discrimination approaches assume that individuals 
prefer certain groups over others; that is, individuals have certain incorporated prejudices (Allport 1954; Becker 1971). Conversely, the theory of "statistical discrimination” assumes that rational and non-prejudiced agents - like frontline workers - make decisions on the grounds of specific individual and group based attributes and behaviors (Arrow 1998; Grohs, Adam, and Knill 2016; Phelps 1972).

In contrast, social construction theory assumes that stereotypes are neither the result of individual preferences nor of typical attributes and behavior, but are due to the fact that some groups, through evaluative and normative cultural characterizations and popular images, are portrayed more positively or negatively in society (Schneider and Ingram 1993). ${ }^{1}$ Perceived group images direct the treatment of the respective societal group and explain why public policies sometimes fail to produce greater equality of citizenship (Ingram, Schneider, and DeLeon 2007, 93). Social constructions refer to value-based cultural images about particular groups of people targeted by a policy, in particular, “(1) the recognition of the shared characteristics that distinguish a target population as socially meaningful, and (2) the attribution of specific, valence-oriented values, symbols, and images to the characteristics” (Schneider and Ingram 1993, 335). Such stereotypes are measurable empirical phenomena, created by politics, culture, socialization, history, the media, religion, literature, and the like.

Social constructions pervade all aspects of political reality and interact with the perceptions of citizens (Pierce et al. 2014). Individual behavior and decision-making can therefore be directed by existing stereotypes "without personally endorsing such stereotypes, without feelings of

\footnotetext{
${ }^{1}$ Stereotypes refer to the prevailing public image, whereas prejudice is a purely individual attitude. Stereotypes may emerge from persisting prejudice; yet, this is not necessarily the case. Moreover, stereotypes may influence the opinions and behavior of individuals without prejudice against specific groups (Vescio and Weaver 2013).
} 
prejudice, and without awareness that such stereotypes could affect one's judgement and behavior” (Vescio and Weaver 2013, 1). We hence expect that frontline workers - without necessarily being truly aware of it - may rely on these mental shortcuts when making policydecisions. As Epp et al. (2017: 169, 173) highlight, such implicit biases go beyond the problem of taste-based discrimination, where individual beliefs or attitudes affect choices. The unit of variation of social constructions is society, not the individual. As a "part of the social heritage of a society", they influence "automatic" mental processes. Even people who do not consciously share this bias may perpetuate the resulting discriminating structures and practices. Nicholson-Crotty and Meier $(2005,228)$ identify three basic conditions for a socially constructed group image: "first the presence of a readily identifiable and socially marginal group with a value-laden stereotype. Second, a moral entrepreneur must focus public attention and fear on the actions of that group. Finally, there must be sufficient political profit to entice a policy champion to place the issue on the political agenda and work to secure passage of a targeted policy”. These three criteria apply to the Swiss case. The public image of immigrants, and in particular of low-skilled or culturally different immigrants, is very negative in Switzerland. Popular images are those of the welfare cheater, the criminal Yugoslavian, or include the general fear that immigrants take away resources such as jobs and welfare benefits from the Swiss population (Rapp 2015). The main moral entrepreneur driving the narrative of alleged "welfare fraud” by immigrants is the Swiss People’s Party (SVP). It continuously frames the public and political discourse on immigrants through pushing forward public votes and policies against foreigners. SVP politicians draw on "emotional and value-laden images and symbols rather than objective representations of 'reality'” (Schneider, Ingram, and DeLeon 2014, 106) to justify their strong anti-immigrant position. Regularly used negatively connoted images - such as the black sheep threatening social cohesion in Switzerland (Manatschal and Rapp, 2015) - may transform themselves into persisting stereotypes that define how both the 
public and policymakers perceive immigrants. The last condition is fulfilled since disability benefits are highly competitive and open to the general public. In this paper, we empirically illustrate the social construction of immigrants and its implications for the course of welfare benefit allocation in Switzerland.

\section{Expectations}

Social constructions are not exogenously given, but subject to change and contentious societal discourses and highly policy-dependent (Schneider and Ingram 1993, 336). Swiss citizens and immigrants do not represent homogenous groups. We draw on both the literature on public support for social spending and the literature on questions of deservingness to empirically define, refine, and identify the dimensions of deservingness and power in the context of disability benefits in Switzerland.

\section{Power}

Schneider and Ingram (1993) define a powerful group as one that has a potential societal and/or political impact, whereby the impact mainly derives from the mere size of the group; their wealth; political resources, such as votes; and their ability to mobilize others (Pierce et al. 2014; Schneider, Ingram, and DeLeon 2014). The political power of (non-naturalized) immigrants in Switzerland is very limited as they are not eligible to vote in elections or popular votes. The Swiss immigration and integration laws further diminish the power of immigrants as they have almost no possibility to take part in political action. Accordingly, we assume that Swiss citizens are per se more powerful than immigrants. Apart from political power, well-educated individuals are considered as powerful, whereas disabled persons, women and families with many children are considered as less influential (Ingram, Schneider, and DeLeon 2007; Petersen et al. 2011; Schneider and Ingram 1993; Schneider and Ingram 1997; van Oorschot 
2006). In addition, elderly individuals are more likely to actively take part in the political process (Schneider, Ingram, and DeLeon 2014). Accordingly, we expect that the most powerful target group of disability benefits are elderly Swiss males who tend to have a good education.

\section{Deservingness}

A growing literature examines who and why specific societal groups are generally considered more deserving of receiving welfare benefits than others (Newton 2005; Petersen 2012; Petersen et al. 2011; van Oorschot 2000; Yoo 2008). The level of need and the reasons why a person is in a needy situation determine deservingness. Persons are seen as the most deserving if they are in general need, for example elderly or sick persons, or if they are not responsible for their situation, for instance having a severe illness by birth or through an accident or being mentally disabled. Conversely, people responsible for their neediness and who constantly complain about their situation range the lowest on the deservingness hierarchy (Einstein and Glick 2016; van Oorschot 2006).

Undoubtedly, however, the most determining factor of deservingness is a shared social or national identity (van Oorschot 2006). Social groups identify themselves as in- and out-groups based on social categorization along distinct cleavage lines, such as race, ethnicity, and citizenship (Tajfel 1982; Tajfel and Turner 1979). Social categorization processes, meaning "our tendency to divide the world into two distinct categories, 'us' and 'them'”, result in discriminatory attitudes and behavior between groups (Crepaz and Damron 2009, 445). Individuals perceive their in-group, that is, the majority within a given country, as superior to an existing out-group, such as immigrants or ethnically diverse groupings. As a result, citizens are generally viewed as more eligible for welfare support than non-natives. Moreover, immigrants are often evaluated and differentiated based on their ethnic origin. In this ethnic 
hierarchy, the more culturally diverse immigrants - compared with the majority of the population - should range the lowest on the deservingness axis. In contrast, culturally similar immigrants are considered as more deserving. In the Swiss case, the cultural similarity distinction is drawn between European and non-European immigrants (Rapp 2015).

We hence expect that severely ill, especially mentally ill, individuals as well as the elderly are generally considered as more deserving of welfare benefits. ${ }^{2}$ In contrast, immigrants particularly non-European immigrants - are considered as less eligible and deserving of public welfare support.

\section{Procedure}

Both public actors and welfare recipients internalize prevailing social constructions. These then shape their perceptions of the legitimacy of claims and needs, interactions, trust, and expectations (Rocha, Knoll, and Wrinkle 2015; Schneider and Sidney 2009). Different social constructions of Swiss and immigrant applicants should hence affect the welfare procedure in terms of its conflict potential and length. According to Schneider and Ingram (1993, 342ff), public actors often treat the contenders who are negatively constructed but powerful with suspicion rather than respect: the government is not really interested in resolving their problems. Because contenders will defend themselves, conflictual interaction is common. As contenders feel that no one will take care of them except for themselves, they use power, manipulation, and subterfuge. Similarly, deviants will have mainly negative experiences when interacting with government officials. "The dominant messages are that they are bad people whose behavior constitutes a problem for others (...) Orientations will be those of angry and

\footnotetext{
${ }^{2}$ Age is both a power and deservingness indicator.
} 
oppressed people who have no faith in government's fairness or effectiveness. They see themselves as alone and as individual players who have no chance of winning in a game that they view as essentially corrupt” (Schneider and Ingram 1993, 342). Conversely, interactions between government officials and positively constructed target groups tend to be more favorable and fair, in particular for the advantaged, who are also powerful.

\section{Welfare benefit allocation}

Social construction theory contends that "there are strong pressures for public officials to provide beneficial policy to powerful, positively constructed target populations and to devise punitive, punishment-oriented policy for negatively constructed groups” (Schneider and Ingram 1993, 334). The perceived social constructions might affect the evaluations and interactions between actors involved in the admission procedure, leading to a biased allocation of welfare benefits - that is, the outcomes of welfare policy delivery (Schneider and Ingram 1993, 337ff; Schneider and Sidney 2009). Benefits tend to be allocated to positively constructed, powerful populations, whereas negatively constructed groups will receive less benefits (Steinacker 2006). We expect these mechanisms to be particularly pronounced for the group of deviants. Frontline workers may fear the power of contenders and be more benevolent towards them in allocating social benefits.

In sum, we expect that both the process and allocation of disability benefits in Switzerland are driven by the social construction of target groups, whereby immigrants should generally be treated less generously than Swiss citizens - depending on a group's position on both the deservingness and power axes. 


\section{Data and methods}

The data for this study stems from a commissioned research project for the Swiss Federal Social Insurance Office (FSIO) in the year 2009 (Bolliger et al. 2010). Our sample comprises 90 case files, of which 48 are Swiss nationals and 42 are non-naturalized immigrants from either Turkey $(\mathrm{N}=10)$ or the former Yugoslavia $(\mathrm{N}=32) .{ }^{3}$ While this sample is not representative of the Swiss population, it draws a very precise picture of the "typical” disability benefit applicant. All 90 applicants are males with a rather low socio-economic background, ranging in age between 35 and 59, who were trained and working in manual jobs, were employed full-time, and diagnosed with a severe physical illness or injury. Men over 40 years old who have worked a manual job account for the largest part of disability benefit recipients in Switzerland. This quasi-most similar systems design focuses on a rather powerless segment of the population in terms of income and type of work, and controls for important determinants of disability (gender, state of health, and professional background). It offers the advantage of holding constant many intervening factors to facilitate a more controlled assessment of the existence and impact of the social construction of immigrants and natives. Table A3 in the online appendix reveals that there are no significant differences between the groups except that Swiss citizens have a slightly higher average education than immigrants.

The 90 applicants were selected in a three-step procedure, based on a full sample of all male applicants in the three cantons (regions) of Zurich, Bern and Vaud. Together, these three cantons account for one third of all disability benefits in Switzerland. They represent the national diversity in terms of language, rural and urban regions, healthcare coverage, economic

\footnotetext{
${ }^{3}$ Three immigrants in our sample hold Swiss citizenship, thus, we counted them as Swiss citizens instead of immigrants.
} 
structure, unemployment, public spending, wealth and the share of immigrants. First, unsuitable cases were sorted out based on statistical data about the applicant's health issue and career. Second, we drew a random sample of 100 case files in each canton from the remaining cases, which were then sorted in a random order. Third, we sequentially checked each case for its compatibility with the above outlined "most similar" criteria until the number of 15 Swiss and immigrant applicants (ethnicity) was reached for each canton (Bolliger et al. 2010: 39-40). The confidential data was quantified by means of in-depth document analyses and quantitative coding of anonymized disability insurance case files. Inter-rater reliability was tested through two rounds of secondary coding of randomly drawn subsamples by a different coder, resulting in subsequent iterative adaptations of the coding scheme and recoding of some variables. The analyzed documents include the full written documentation of each procedure, including memoranda; letters by applicants, clerks and other involved persons; reports and expertise by medical experts or treating doctors, employers, lawyers, other insurances, and social assistance officers, both the regional medical service and independent medical observation centers; reports by reintegration experts and professional advisors; and official disability insurance orders. Our very detailed data bears distinct advantages to prior studies relying on experimental data (Pierce et al. 2014). The allocation of disability benefits is a very lengthy process that involves many different actors. An experimental design cannot cover this complexity of interactions. In addition, this data allows us to make claims about how street-level bureaucrats actually perceive different ethnic groups (see detailed measures below). Yet, this significant gain in internal validity simultaneously reduces external validity.

In what follows, we describe our measures for the social construction of target groups and its consequences as defined earlier (overview and descriptive statistics see Table A1, online appendix).

\section{Dependent measures}


The duration of the procedure in days is our first, procedure-related dependent variable. Our second dependent variable measures the outcome of the procedure as a binary variable $(0=$ no pension, 1=pension entitlement). ${ }^{4}$ Finally, a crucial variable is the objective evaluation of an applicant's incapacity to work as a result of the different medical and reintegration assessments, following purely legally criteria. To obtain this evaluation, the disability insurance office distracts the earned income that remains after accounting for the health damage and the undertaken professional reintegration measures, from the income that could be earned without health damage (the "validity income"). The difference, expressed in per cent of the validity income, is the so-called "degree of disability" which, legally speaking, forms the sole basis for calculating the benefits for the applicants (Informationsstelle AHV/IV and Bundesamt für Sozialversicherungen 2008). As a dependent measure, it represents one outcome of the procedure; as an independent measure, it helps us clarify the degree to which social constructions matter for benefit allocation once this objective assessment is controlled for.

\section{Power and deservingness indicators}

For assessing the objective social construction of target groups, we rely on four basic indicators. The deservingness of groups is primarily based upon an individual's nationality. Immigrants are defined here as non-Swiss citizens, who are further distinguished as immigrants from the former Yugoslavia (European immigrants) or Turkey (non-European immigrants). We expect that nationality is the main factor driving an unequal treatment of welfare applicants, based on a frontline worker's cognitive evaluation of immigrant status and the associated stereotypes. As to the mental health status of an applicant, a diagnosed mental health issue

\footnotetext{
${ }^{4}$ The actual degree of pension allocation varies between no, quarter, half, or full pension. However, in the present sample almost no one received a quarter or half pension. Accordingly, we dichotomized this indicator.
} 
should indicate greater perceived deservingness. Age captures both deservingness and power. The last indicator, educational attainment, exclusively captures the power dimension.

The in-depth coding allowed us to additionally obtain fine-grained information about the perceptions of the frontline workers involved, presented later in the empirical analysis. As the applicant files vary in size between eight and 147 documents, not all files comprise the same set of variables. This leads to a high number of missing values for these "subjective" variables.

\section{Method}

To analyze these data, we use different approaches. First, we validate and empirically identify the social construction of welfare applicants of our cases through a k-means cluster analysis based on the above-presented four power and deservingness measures. In contrast to standard cluster analysis, the k-means algorithm is a theory-driven approach which defines the number of clusters a priori. This cluster method is the most appropriate way of finding clusters in our data that reflect the social construction theory, with its four distinct 'cells' ${ }^{5}$ In a second step, we assess if this social construction has an influence on both the duration and the actual outcome of the procedure. The potential impact on all three dependent variables is tested by multiple regression analyses - linear models testing the influences on the duration and the evaluation of the incapacity to work, and logit models explaining the differences in the probability of receiving a pension. Given that our analysis is based on a rather small, nonrepresentative sample, we implement a Bayesian estimation approach. This method performs

\footnotetext{
${ }^{5}$ K-means clustering is widely used and studied to minimize a formal objective function (Kanungo et al. 2002, 881). Its algorithm finds the closest mean for every observation in the data. Being closely related to the idea of principal component analyses, it is often referred to as prototype clustering. We additionally estimated a standard cluster analysis based on Euclidian distances which rendered almost identical results (not shown here).
} 
better than frequentist approaches when basic stochastic assumptions are violated (sample cannot be drawn indefinitely) or the number of observations is small (Jackman 2009). ${ }^{6}$

\section{Results}

We first analyze whether our assumption holds that applicants' deservingness is mainly a function of their nationality. To this end, we empirically determine the applicants' actual positions as suggested by Schneider et al. (2014). We then proceed to the explanatory analysis.

\section{Social construction in Swiss disability benefit allocation}

Figure 1 presents the results of the k-means cluster analysis, revealing a four-group structure in our data using the allocation of a welfare benefit as indicator for actual deservingness. ${ }^{7}$ The displayed positions of the clusters reflect the mean-values of the observed variables within each cluster. The upper-right quadrant is empty as we have only three naturalized immigrants in our sample. Unsurprisingly, elderly and well-educated Swiss citizens constitute the advantaged group $(\mathrm{N}=12)$. Contrary to our expectations, Swiss citizens may also be seen as undeserving:

\footnotetext{
${ }^{6}$ Contrary to frequentist approaches, Bayesian inference makes posterior probability statements instead of distinct statements about coefficient estimates. Bayesian analysis relies on a probability based approach that updates a priori assumptions about the phenomenon at hand by means of given data which results in informative probability assumptions - the posterior probability. Other than standard frequentist approaches, there is no need to fulfill a minimum number of cases or a specific data generation process (Jackman 2009).

${ }^{7}$ We additionally tested the group structure using latent class factor analysis (not shown here), with very similar results to the cluster analysis. Furthermore, we tested two-group and three-group solutions against the presented four-group solution. The four-group solution always achieved the best results.
} 
diametrically opposed to the advantaged group, we find the deviants, who are (rather) young Swiss and immigrants from the former Yugoslavia without mental health issues $(\mathrm{N}=37)$. The group of older immigrants - both from the former Yugoslavia and Turkey - who have a lowlevel education, but were diagnosed with mental health issues, ranges somewhere between the deviants and dependents categories $(\mathrm{N}=25)$. Unexpectedly, we cannot confirm that European and non-European immigrants differ in their deservingness. The last cluster comprises the dependents, who are rather low-educated, medium aged Swiss citizens with diagnosed mental health issues $(\mathrm{N}=12)$. The dependents have a higher deservingness than the advantaged, indicated by their position on the far-left.

\section{FIGURE 1 HERE}

In sum, Figure 1 supports our assumption that immigration status is the main factor dividing the deserving from the undeserving. We now further test the implications of these constructions with the help of regression analysis.

\section{Explanatory analysis}

To address our expectations, we first take a look at cross-tabulations between our main variables of interest and immigrants (Table 1), before we estimate Bayesian regression models which test the influence of the above presented deservingness and power variables on the procedure and its outcomes (see Tables 2 and 3) ${ }^{8}$ The results in Table 1 reveal that the mean

${ }^{8}$ All models were calculated in Stata version 14.2 (bayesmh) using Markov Chain Monte Carlo (MCMC) 
differences between Swiss and non-Swiss applicants are statistically significant for all three dependent measures, namely the duration of the allocation procedure, the evaluation of one's incapacity to work as well as the allocation of disability benefits. The question, however, is if these findings hold, when we control for confounding factors.

\section{TABLE 1 HERE}

\section{TABLE 2 HERE}

For an easy interpretation of the Bayesian estimation results, the mean and the $90 \%$ credible interval of the posterior distribution are provided. The mean is the average effect of the respective influence variable on the outcome variable, and the credible interval gives a sense of the statistical reliability of this estimate. If the credibility interval does not include zero, we speak of relevant coefficients, which corresponds to significant coefficients in frequentist terms. Model 1 in Table 2 reveals, first, that an applicant's educational level and whether the respondent is an immigrant from the former Yugoslavian states decisively influences the duration of the application procedure. For this immigrant group, the application procedure can take 138 to 714 days longer than for Swiss applicants. Having a medium level of education compared to a low educational level significantly shortens the duration of the procedure, on

estimation (20,000 iterations, burn-in 5,000). As fully Bayesian analyses require the specification of priors for all unknown parameters, we used normal informative priors based on subjective selection for coefficients (for more details on this kind prior selection see Berger (1993)) and (conjugate) inverse gamma priors, $\sigma_{y}^{2}, \sim \Gamma^{-1}(\epsilon, \epsilon)$ with $\epsilon$ set to 0.001 for variance components (see Stegmueller 2013). No signs of non-convergence were detected. All models show a good acceptance rate and efficiency. Additional to these Bayesian models, we estimated standard regression models (see Table A4, online appendix) which yield very similar results. 
average by 410 days. To capture the conflict potential of the procedure, we added the disagreement between doctors and the IV officer on either the applicant's health status or his incapacity to work to model 1 . Unsurprisingly, a higher disagreement on the health and incapacity status of the applicant may prolong the overall duration of the procedure by 43 to 387 days. While having mental health issues shows a negative effect, it fails to be relevant for explaining the duration of the procedure. The same applies to the age effect. Overall, these results support our expectation that immigrant status plays a role in the allocation procedure of welfare benefits. Even when controlling for a lack of clarity about the applicant's capacity to work and health status, being from the former Yugoslavia prolongs the whole procedure. As expected, both deservingness and power matter.

Model 2 assesses the influence on the evaluation of the incapacity to work. Being a Turkish immigrant has a relevant impact on this objective measure of deservingness as a result of the evaluations performed during the procedure. The same goes for age, which is unsurprising, as younger applicants can more easily be reintegrated into the labor market. Overall, the first two models confirm our expectations: the more powerful European immigrants face more contentious procedures, whereas non-European immigrants are seen as less deserving.

Table 3 presents our findings concerning the allocation of a disability pension. ${ }^{9}$ Model 3 shows that being a Turkish immigrant makes a relevant difference for receiving a partial or full pension compared to Swiss natives. Conversely, the chances of immigrants from the former Yugoslavia to receive a disability pension does not differ from those of a Swiss applicant.

\footnotetext{
${ }^{9}$ Given the procedural nature of the presented models in Table 2 and 3, a path model could be appropriate here. We estimated additional SEM models which, however, did not render satisfying or relevant results. A plausible reason is that the models had too less observation for too many parameters.
} 
Importantly, model 4 controls for the evaluation of the incapacity to work, which should be the only factor that determines the calculation of a pension according to law. Here, immigration background should no longer play a relevant role.

\section{TABLE 3 HERE}

Yet we observe in model 4 that even when controlling for the objective assessment of disability, being a Turkish immigrant still lowers the probability of receiving a pension. Conversely, being diagnosed with mental health issues enhances the probability of receiving a pension: these are particularly needy clients. It is not surprising that the officer's evaluation of the applicant's degree of disability explains the largest part of the observed variance in the dependent variable - so it should. Last, the results for age and education do not show a clear direction. ${ }^{10}$ This supports our assumption that non-European immigrants will be least likely to receive a pension - even if we control for the objective application of the legal disability criteria. In sum, all four models reveal an unequal treatment of immigrants in the procedure and outcome of disability benefits. These results hold even when accounting for objective, procedure-specific indicators.

One relevant feature of the presented results is that our sample comprises almost only presumably powerless, that is non-naturalized, immigrants. Naturalization is only possible after 12 years of residing in Switzerland. To realistically assess the social construction of immigrant groups in Switzerland, it is more meaningful to take into consideration the degree of their

\footnotetext{
${ }^{10}$ We further tested potential interactive relationships between nationality and the other measures (age, education, mental health, years having lived in Switzerland), but could not find any relevant interactive relationship between these. Moreover, there could be a curvilinear effect of years having lived in Switzerland. Additional models including this effect did not reveal any significant or relevant results.
} 
integration as a potential power indicator. The time the applicant has been living in Switzerland approximates this. In our sample, the immigrant applicants have been living in Switzerland between 8 and 59 years, and 22 years on average. Table 4 presents estimates for the subgroup of immigrants, including the above variables and the additional integration measure. Both the duration and the allocation of benefits are regressed on these indicators.

\section{TABLE 4 HERE}

Looking at model 4, we may conclude that education as well as the time the immigrantapplicant has been living in Switzerland relevantly diminish the overall duration of the procedure. The fifth model shows that both the time spent in Switzerland and having mental health issues determine the probability of receiving a pension. Yet, being Turkish or from the former Yugoslavia no longer makes a relevant difference in both models. What these results suggest is that the observed differences between the two immigrant groups are mainly a function of their power and deservingness, not of nationality per se. Their degree of integration into Swiss society could in fact indicate both, since it also affects the perceived outgroup status. Until now, we addressed only how objective measures influence the allocation of benefits, but not how frontline workers perceive specific groups - that is, the actual social construction that underlies these results. We now implement measures representing the subjective perception and evaluation by the IV officers and medical experts of perceived differences. ${ }^{11}$ Indicators

\footnotetext{
${ }^{11}$ Note that these indicators constitute perceptions of the welfare workers involved in the evaluations, rather than objective facts or behaviors of the applicants. Empirical analyses have shown that the share of immigrant recipients of disability benefits is attributable to the equally twice as high share of immigrant applicants, rather than to the procedure itself. There is no empirical evidence that immigrants have an objectively higher tendency
} 
for deservingness are (1) perceived existence of non-verifiable pain symptoms; (2) perceived tendency to express mental stress as physical symptoms; (3) the suspicion of simulated symptoms. We can further illustrate the complexity and contentiousness of the procedure with measures of (4) the number of doctors consulted; (5) the number of documents in the file; (6) the involvement of a lawyer in the procedure; (7) whether the applicant issued a complaint or objection in court; (8) experts' disagreement about the applicant's health status; (9) experts' disagreement about the applicant's capacity to work; and (10) the disagreement between applicant and IV officer on the applicant's capacity to work. A descriptive analysis and comparisons between our three nationality groups illustrate these subjectively perceived evaluations of the applicants and the complexity and contentiousness of the procedures. This analysis may clarify the above observed biased treatments of Swiss citizens and immigrants in the allocation procedure and outcome of disability benefits. Table 5 shows the average values and mean percentages for these variables, and the statistical significance between the three groups.

\section{TABLE 5 HERE}

In line with the above analyses, we find a very strong tendency of immigrants being socially constructed as more suspicious and, thus, as less deserving than Swiss applicants in the eyes of the medical actors and insurance employees involved in the procedure. Immigrant applicants are considerably more often perceived to express psychological issues, like stress, through

to cheat or simulate (Bolliger et al. 2010). 
physical symptoms (93 and 100 percent compared to 53 percent), to experience pain that does not have a verifiable cause (50 percent compared to 23 percent), or to report symptoms that do not seem to exist (30 and 37 percent compared to 0 percent). It is therefore much less clear whether immigrant applicants are truly suffering and responsible for their situations or not (i.e., needy). It is, however, clear that they are more often perceived to be overly complaining. Language issues and cultural patterns of communicating illness and pain play an important role in explaining these mechanisms that trigger social constructions (Bolliger et al. 2010). If social construction mainly relies on immigrant status, the disability procedures should also be more complex, conflictual, and characterized by suspicion for undeserving target groups. This is indeed the case: the disability procedures of immigrants comprise more medical clarifications, larger file sizes, more disagreements between experts, more disagreements between the applicant and the IV officer, more lawyers involved in the process, and more legal complaints or objections than those of Swiss applicants.

\section{Discussion}

Our findings offer a nuanced portrait of the biases in the decisions taken by frontline workers. The above results, regression and descriptive, support the general idea that target groups are socially constructed based on their deservingness and power. Nationality determines deservingness. It matters whether you are an immigrant or not; and it is important where you originally come from. Depending on these factors, the duration of the application procedure is shorter and you are more likely to receive a pension. Being an immigrant from the former Yugoslavian countries prolongs the application procedure. If you are an immigrant from Turkey, you are decisively less likely to receive a pension. These effects persist even if we control for the assessment according to objective, legal criteria - hence undermining the principle of equal treatment of welfare clients. However, the differences between immigrants 
seem to be in large part a function of their power and deservingness, rather than simply of nationality. These stereotypes are reflected in the welfare workers' perceptions of immigrants being more suspicious and less needy. They affect the contentiousness and complexity of the procedure.

We cannot however, say that immigrants are per se, by law or policy design, disadvantaged in the disability procedure. Rather, all applicants undergo close scrutiny and ample evaluation. What we can say is that their perceived degree of deservingness and power influences how the legal criteria are applied. Overall, Swiss citizens who were diagnosed with mental health issues have the best chances to receive a disability pension. The prospects for immigrants from the former Yugoslavian states are more optimistic than those for Turkish applicants: while they often must endure a longer procedure, their probability of receiving a pension eventually does not differ from the general probability Swiss citizens have.

Before discussing the implications of our results, we want to emphasize that these should be handled with care. Frontline decisions have manifold reasons other than social constructions (Lipsky 1980; Maynard-Moody and Musheno 2012; Meyers et al. 2001; Scott 1997; Thomann 2015; Tummers et al. 2015). Shortcomings of our dataset particularly affected the comparability of some indicators and meant many missing values on potential influences. Our sample also (deliberately) was not representative of the Swiss population, but of disability benefit applicants with a high likelihood to receive pensions. While this helped create a quasimost-similar system design, we are not able to draw any conclusions for groups outside of this sample. Future research should address similar questions in other European countries and concerning other social benefits and target groups, particularly women (Petersen et al. 2011). 


\section{Conclusions}

Our study adds to existing evidence of unequal treatment of target groups in welfare service delivery, often based on race. Stereotypes about immigrants may not only define who deserves help and who does not, but also who will ultimately receive it in modern European welfare states. The case of Switzerland is in many respects representative of current developments regarding immigration, anti-immigrant attitudes, and their political mobilization in Western Europe. While the implications of these developments for public opinion and party politics are relatively well-explored, this is less the case for administrative practices.

Yet studies like ours point to an urgent truth: "it is of great convenience, both theoretically and practically, to assume that citizen $\mathrm{A}$ is the same as citizen $\mathrm{B}$ and that they both receive public services in equal measure. This assumption may be convenient, but it is obviously both illogical and empirically inaccurate” (Frederickson 1990, 228). As the notion of "feed-forward effects" entails (Pierce et al. 2014) and the recent policing crisis in the United States amply demonstrates, an unequal treatment of target groups by bureaucracies has wide-ranging consequences for democracy and society at large (Deleon and Weible 2010; Epp et al. 2017; Liang 2016; Piatak 2015). Discrimination in policy implementation has decisive impacts on both the attitudes and political behavior of the respective group and the public perception of this group. A biased treatment by policymakers and frontline workers sends distinct messages about the group’s position in society and their possibilities to integrate into society and change the status quo (Moynihan and Herd 2010). Immigrants, for example, may not seek the help of the police or courts and rely on self-justice instead as they may believe that they will not be heard based on their prior treatment by frontline workers and policymakers (Epp et al. 2017).

The fact that stereotypes affect public action in the sphere of the presumably neutral and technocratic bureaucracy gains saliency as anti-immigration attitudes continue to be on the rise. 
We have shown that even in a context of a very tight, "objective” legal criteria for welfare eligibility, in a controversial political climate and stressful environment, bureaucrats may treat some clients as more equal than others (Grohs, Adam, and Knill 2015). In this context, the political willingness to pay attention to a discriminatory treatment of immigrant welfare applicants is lacking. Rather, the findings by Bolliger et al. $(2010,5)$ were received politically as a sign that "the higher share of immigrant recipients is not caused by the allocation procedure”. Political contexts differ between countries: in August 2016, the British Prime Minister Theresa May, for instance, ordered the government to audit how public services treat people from different backgrounds in order to reveal racial disparities across the country's public sector.

Even in a context of political willingness for change, deeply rooted stereotypes are a difficult target for reform. Scholars point to the importance of law, management, education, and exhortation to achieve greater social equity in public service delivery (Deleon and Weible 2010; Gooden and Portillo 2011; Johnson 2012). Simultaneously, research on frontline service delivery emphasizes how the need to cope with pressures from austerity and New Public Management can undermine these goals, forcing service deliverers to prioritize some clients over others (e.g., Danziger and Seefeldt 2003; Maynard-Moody and Musheno 2012; Meyers et al. 2001; Thomann 2015; Tummers et al. 2015). We have shown that institutional-cultural differences to the welfare system of the United States do not mitigate the discrimination of immigrants in the Swiss case. Pessimistically speaking, our results raise fundamental questions concerning how the equal treatment of all welfare applicants can be guaranteed in such times. At best, our findings can raise the awareness of public managers and practitioners involved in both political and everyday decisions on the allocation of public resources towards vulnerable populations. In any case, our study suggests that social equity issues deserve more attention by scholars studying the policy implications of immigration in contemporary Europe. 


\section{Acknowledgements}

We are very grateful to David Kaufmann, Ioannis Papadopoulos, Jale Tosun, Nadine van Engen, and Kent Weaver for their thoughtful comments on earlier versions of this paper. In addition, we thank Claire Dunlop, Richard Greggory Johnson III, Susan Gooden, and Blue Woolridge for their very helpful literature recommendations. We would also like to thank the three anonymous reviewers as well as the Editor of the Policy Studies Journal for their valuable comments.

\section{References}

Allport, Gordon W. 1954. The nature of prejudice. Cambridge: Addison Wesley.

Armingeon, Klaus. 2001. “Institutionalising the Swiss welfare state”. West European Politics 24 (2): 145-168.

Arrow, Kenneth J. 1998. "What Has Economics to Say about Racial Discrimination?” The Journal of Economic Perspectives 12 (2): 91-100.

Becker, Gary S. 1971. The economics of discrimination. 2d ed. Economics research studies of the Economics Research Center of the University of Chicago. Chicago: University of Chicago Press.

Berger, James O. 1993. Statistical Decision Theory and Bayesian Analysis. 2. ed. New York: Springer.

Bolliger, Christian, Isabelle Stadelmann-Steffen, Eva Thomann, and Christian Rüefli. 2010. Migrantinnen und Migranten in der Invalidenversicherung. Verfahrensverläufe und vorgelagerte Faktoren. Report Number 3/10. Bern: BSV.

Boräng, Frida. 2015. "Large-scale solidarity? Effects of welfare state institutions on the 
admission of forced migrants.” European Journal of Political Research 54(2): 216-31.

Brodkin, Evelyn Z. 1993. “The Making of an Enemy: How Welfare Policies Construct the Poor.” Law \& Social Inquiry 18(4): 647-670.

Crepaz, Markus M. L., and Regan Damron. 2009. “Constructing Tolerance: How the Welfare State Shapes Attitudes about Immigrants.” Comparative Political Studies 42(3): 437-63.

Danziger, Sandra K., and Kristin S. Seefeldt. 2003. "Barriers to Employment and the 'Hard to Serve’: Implications for Services, Sanctions, and Time Limits.” Social Policy \& Society 2 (2): 151-60.

Deleon, Peter and Christopher M. Weible. 2010. “Policy Process Research for Democracy: A Commentary on Lasswells Vision.” International Journal of Policy Studies 1(2): 23-34.

DiAlto, Stephanie J. 2005. “From 'problem minority’to ‘model minority’: The changing social construction of Japanese Americans.” In Deserving and entitled: Social constructions and public policy, eds. Anne L. Schneider and Helen M. Ingram. Albany: State University of New York Press, 81-103.

Einstein, Katherine L., and David M. Glick. 2016. “Does Race Affect Access to Government Services? An Experiment Exploring Street-Level Bureaucrats and Access to Public Housing.” American Journal of Political Science early view, 1-17. doi:10.1111/ajps.12252.

Epp, Charles R., Steven Maynard-Moody, and Donald Haider-Markel. 2017. "Beyond Profiling: The Institutional Sources of Racial Disparities in Policing.” Public Administration Review 77(2): 168-178.

Fineman, S. 1998. "Street-level Bureaucrats and the Social Construction of Environmental Control.” Organization Studies 19(6): 953-74.

Frederickson, H. George. 1990. "Public Administration and Social Equity." Public 
Administration Review 50(2): 228-37.

Freitag, Markus, and Carolin Rapp. 2013. “Intolerance Toward Immigrants in Switzerland: Diminished Threat Through Social Contacts?” Swiss Political Science Review 19(4): 42546.

Garand, James C., Ping Xu, and Belinda C. Davis. 2017. Immigration Attitudes and Support for the Welfare State in the American Mass Public. American Journal of Political Science 61 (1): 146-162.

Gooden, Susan T. 2006. “Addressing racial disparities in social welfare programs: Using social equity analysis to examine the problem.” Journal of health \& social policy 22(2): 1-12.

Gooden, Susan, and Shannon Portillo. 2011. “Advancing social equity in the Minnowbrook tradition.” Journal of Public Administration Research and Theory 21(suppl 1): i61-i76.

Grohs, Stephan, Christian Adam, and Christoph Knill. 2016. “Are Some Citizens More Equal than Others? Evidence from a Field Experiment.” Public Administration Review 76(1): 155164.

Informationsstelle AHV/IV and Bundesamt für Sozialversicherungen. 2008. Leistungen der Invalidenversicherung (IV) 4.01d. Version 1. January 2008.

Ingram, Helen, Anne L. Schneider, and Peter DeLeon. 2007. “Social construction and policy design.” Theories of the policy process 2: 93-126.

Jackman, Simon. 2009. Bayesian Analysis for the Social Sciences. Chichester, UK: Wiley.

Jensen, Carsten, and Michael B. Petersen. 2016. “The Deservingness Heuristic and the Politics of Health Care." American Journal of Political Science early view: 1-16. doi:10.1111/ajps.12251.

Johnson, Richard Greggory. 2012. "Promoting Social Equity in Public Administration: A 
Much Needed Topic in the Twenty-First Century.” Public Administration Review 72(3): 471-473.

Kanungo, Tapas, D. M. Mount, N. S. Netanyahu, C. D. Piatko, R. Silverman, and A. Y. Wu. 2002. "An efficient k-means clustering algorithm: Analysis and implementation.” IEEE Trans. Pattern Anal. Machine Intell. 24 (7): 881-92.

Lasswell, Harold D. 2012. Politics: Who gets what, when, how. Whitefish, Mont.: Literary Licensing.

Liang, Jiaqi. 2016. “The Shadow of the Politics of Deservedness? The Implications of GroupCentric Policy Context for Environmental Policy Implementation Inequalities in the United States.” Journal of Public Administration Research and Theory 26(3): 552-570.

Lipsky, Michael. 1980. Street-level bureaucracy: Dilemmas of the individual in public services. New York: Russell Sage.

Manatschal, Anita, and Carolin Rapp. 2015. „Welche Schweizer wählen die SVP und warum?“ In Wahlen und Wählerschaft in der Schweiz, eds. Markus Freitag and Adrian Vatter. Zuerich: NZZ Verlag, 187-216.

Maynard-Moody, Steven, and Michael Musheno. 2012. "Social Equities and Inequities in Practice: Street-Level Workers as Agents and Pragmatists.” Public Administration Review 72(s1): S16-S23.

Meyers, Marcia K., Norma M. Riccucci, and Irene Lurie. 2001. “Achieving Goal Congruence in Complex Environments: The Case of Welfare Reform.” Journal of Public Administration Research and Theory 11(2): 165-202.

Monnat, Shannon M. 2010. “The Color of Welfare Sanctioning: Exploring the Individual and Contextual Roles of Race on TANF Case Closures and Benefit Reductions.” Sociological 
Quarterly 51(4): 678-707.

Moynihan, Donald, and Pamela Herd. 2010. "Red tape and democracy: How rules affect citizenship rights.” The American Review of Public Administration 40(6): 654-670.

Newton, Lina. 2005. "It is not a question of being anti-immigration: categories of deservedness in immigration policy making.” In Deserving and entitled: Social constructions and public policy, eds. Anne L. Schneider and Helen M. Ingram. Albany: State University of New York Press, 139-67.

Nicholson-Crotty, Jill \& Sean Nicholson-Crotty. 2004. “Social Construction and Policy Implementation: Inmate Health as a Public Health Issue”. Social Science Quarterly 85(2): 240-256.

Nicholson-Crotty, Sean, and Kenneth J. Meier. 2005. "From perception to public policy: Translating social constructions into policy designs.” In Deserving and entitled: Social constructions and public policy, eds. Anne L. Schneider and Helen M. Ingram. Albany: State University of New York Press, 223-242.

Pierce, Jonathan J., Saba Siddiki, Michael D. Jones, Kristin Schumacher, Andrew Pattison, and Holly Peterson. 2014. “Social construction and policy design: A review of past applications.” Policy Studies Journal 42(1): 1-29.

Petersen, Michael B. 2012. “Social Welfare as Small-Scale Help: Evolutionary Psychology and the Deservingness Heuristic.” American Journal of Political Science 56(1): 1-16.

Petersen, Michael B., Rune Slothuus, Rune Stubager, and Lise Togeby. 2011. “Deservingness versus values in public opinion on welfare: The automaticity of the deservingness heuristic.” European Journal of Political Research 50(1): 24-52.

Phelps, Edmund S. 1972. "The Statistical Theory of Racism and Sexism.” The American 
Economic Review 62(4): 659-61.

Piatak, Jaclyn S. 2015. "Understanding the Implementation of Medicaid and Medicare: Social Construction and Historical Context." Administration \& Society early view. doi: 0095399715581030.

Rapp, Carolin. 2015. "More diversity, less tolerance? The effect of type of cultural diversity on the erosion of tolerance in Swiss municipalities.” Ethnic and Racial Studies 38(10): 17791197.

Rocha, Rene R., Benjamin R. Knoll, and Robert D. Wrinkle. 2015. “Immigration Enforcement and the Redistribution of Political Trust.” The Journal of Politics 77(4): 901-913.

Sager, Fritz, and Eva Thomann. 2016. "Multiple streams in member state implementation: politics, problem construction and policy paths in Swiss asylum policy.” Journal of Public Policy early view: 1-28. doi:10.1017/S0143814X1600009X.

Schneider, Anne L., and Helen M. Ingram. 1993. “Social Construction of Target Populations: Implications for Politics and Policy.” The American Political Science Review 87(2): 334347.

Schneider, Anne L., and Helen M. Ingram. 1997. Policy design for democracy. Lawrence, Kansan: University Press of Kansas.

Schneider, Anne L., and Mara Sidney. 2009. "What Is Next for Policy Design and Social Construction Theory?” Policy Studies Journal 37(1): 103-119.

Schneider, Anne L., Helen M. Ingram, and Peter DeLeon. 2014. “Democratic Policy Design: Social Construction of Target Populations”. In Theories of the Policy Process, eds. Paul A. Sabatier and Christopher M. Weible. Boulder, Colorado: Westview Press, 105.149.

Schram, Sanford F., Joe Brian Soss, and Richard Carl Fording (eds.). 2010. Race and the 
politics of welfare reform. Ann Arbor: University of Michigan Press.

Scott, Patrick G. 1997. “Assessing Determinants of Bureaucratic Discretion: An Experiment in Street-Level Decision Making.” Journal of Public Administration Research and Theory 7(1): 35-58.

Smedley, Brian D. , Adrienne Y. Stith , and Alan R. Nelson , eds. 2002 . Unequal Treatment: Confronting Racial and Ethnic Disparities in Health Care. Washington, DC: National Academies Press.

Steinacker, Annette. 2006. "Externalities, Prospect Theory, and Social Construction: When Will Government Act, What Will Government Do?” Social Science Quarterly 87(3): 45976.

Stegmueller, Daniel. 2013. "How Many Countries for Multilevel Modeling? A Comparison of Frequentist and Bayesian Approaches.” American Journal of Political Science 57 (3): 74861.

Tajfel, Henri. 1982. "Social Psychology of Intergroup Relations.” Annual Review of Psychology 33(1): 1-39.

Tajfel, Henri, and John C. Turner. 1979. “An integrative theory of intergroup conflict.” In The Social Psychology of Intergroup Relations, William G. Austin and Stephan Worchel (eds.). Monterey: Brooks/Cole, 33-47.

Terum, Lars, Gaute Torsvik, Inge, and Einar Øverbye. 2017. “Discrimination Against Ethnic Minorities in Activation Programme? Evidence from a Vignette Experiment.” Journal of Social Policy (online first publication), doi:10.1017/S0047279417000113

Thomann, Eva. 2015. “Is Output Performance all about the Resources? A fuzzy-set qualitative comparative analysis of street-level bureaucrats in Switzerland.” Public Administration 
93(1): 177-194.

Tummers, Lars L. G., Victor Bekkers, Evelien Vink, and Michael Musheno. 2015. “Coping

During Public Service Delivery: A Conceptualization and Systematic Review of the Literature.” Journal of Administration Research and Theory 25(4): 1099-1126.

Vescio, Theresa, and Kevin Weaver. 2013. "Prejudice and Stereotyping”. Oxford Bibliographies Online Database. doi: http://dx.doi.org/10.1093/obo/9780199828340-0097 van der Waal, Jeroen, Willem de Koster, and Wim van Oorschot. 2013. "Three Worlds of Welfare Chauvinism? How Welfare Regimes Affect Support for Distributing Welfare to Immigrants in Europe.” Journal of Comparative Policy Analysis: Research and Practice 15(2): 164-81.

van Oorschot, Wim. 2000. "Who should get what, and why? On deservingness criteria and the conditionality of solidarity among the public.” Policy\&Politics 28(1): 33-48.

—. 2006. "Making the difference in social Europe: Deservingness perceptions among citizens of European welfare states.” Journal of European Social Policy 16(1): 23-42.

Watkins-Hayes, Celeste. 2009. "Race-ing the bootstrap climb: Black and latino bureaucrats in post-reform welfare offices.” Social Problems 56(2): 285-310.

Wyssmueller, Chantal, and Denise Efionayi, eds. 2007. Literatur-und Datenstudie zum Thema Migration und Invalidenversicherung: Revidierter Schlussbericht: Neuchâtel: Forum suisse pour l'étude des migrations et de la population, SFM.

Yoo, Grace J. 2008. "Immigrants and Welfare: Policy Constructions of Deservingness.” Journal of Immigrant \& Refugee Studies 6(4): 490-507. 


\section{Tables and Figures}

TABLE 1: Descriptive analysis - Differences between citizens and non-citizens

\begin{tabular}{lcccccc}
\hline & \multicolumn{2}{c}{ Swiss } & \multicolumn{2}{c}{ non-Swiss } & & \\
& mean & sd & mean & sd & F & p \\
\hline Duration of procedure & 940.67 & 664.28 & 1640.50 & 732.92 & 22.58 & 0.00 \\
Evaluation of incapacity to work & 52.51 & 37.20 & 38.80 & 34.02 & 3.27 & 0.07 \\
Allocation of disability benefit & 0.50 & 0.51 & 0.26 & 0.44 & 5.55 & 0.02 \\
\hline
\end{tabular}

Note: Group-comparisons/significance tests based on Sidak test statistics. 
TABLE 2: Regression results - duration of allocation procedure and evaluation of incapacity to work

\begin{tabular}{|c|c|c|c|c|c|c|}
\hline & \multicolumn{3}{|c|}{$\begin{array}{c}\text { Model } 1 \\
\text { Duration of procedure }\end{array}$} & \multicolumn{3}{|c|}{$\begin{array}{c}\text { Model } 2 \\
\text { Evaluation of incapacity to } \\
\text { work }\end{array}$} \\
\hline & Mean & $10 \%$ & $90 \%$ & Mean & $10 \%$ & $90 \%$ \\
\hline \multicolumn{7}{|l|}{ Deservingness } \\
\hline \multicolumn{7}{|l|}{ Nationality $^{\mathrm{a}}$} \\
\hline former Yugoslavia & 425.64 & {$[138.08$} & 714.25] & -56.13 & {$[-127.77$} & 14.11] \\
\hline Turkey & 113.39 & {$[-323.72$} & 562.91] & -116.87 & {$[-227.50$} & $-4.56]$ \\
\hline Mental illness diagnosed & -90.21 & {$[-352.50$} & 178.13] & 19.41 & {$[-49.03$} & 87.57] \\
\hline \multicolumn{7}{|l|}{ Powerfulness } \\
\hline Age & -17.80 & {$[-35.83$} & $0.28]$ & -12.48 & {$[-16.99$} & $-7.95]$ \\
\hline Educational level & -410.82 & {$[-721.18$} & $-104.87]$ & -61.90 & {$[-139.72$} & 15.77] \\
\hline \multicolumn{7}{|l|}{ Procedure specific influence } \\
\hline disagreement on health status & 215.10 & {$[43.50$} & 387.38] & & & \\
\hline Intercept & 2470.35 & {$[1673.92$} & 3268.43] & 19.41 & {$[-49.03$} & 87.57] \\
\hline $\mathrm{N}$ & & 86 & & & 85 & \\
\hline
\end{tabular}

Note: ${ }^{a}$ reference category Swiss; mean posterior distributions of linear and logistic Bayesian regression coefficients and 90 percent credibility intervals (in squared brackets).

Bold: relevant coefficients. 
TABLE 3: Regression results - outcome of allocation procedure

\begin{tabular}{|c|c|c|c|c|c|c|}
\hline & \multicolumn{3}{|c|}{$\begin{array}{c}\text { Model 3 } \\
\text { allocation of disability } \\
\text { benefit }\end{array}$} & \multicolumn{3}{|c|}{$\begin{array}{c}\text { Model } 4 \\
\text { allocation of disability } \\
\text { benefit }\end{array}$} \\
\hline & Mean & $10 \%$ & $90 \%$ & Mean & $10 \%$ & $90 \%$ \\
\hline \multicolumn{7}{|l|}{ Deservingness } \\
\hline \multicolumn{7}{|l|}{ Nationality $^{\mathrm{a}}$} \\
\hline former Yugoslavia & -0.54 & {$[-1.50$} & $0.40]$ & -1.35 & {$[-3.21$} & $0.39]$ \\
\hline Turkey & -2.49 & {$[-4.95$} & $-0.41]$ & -4.44 & {$[-7.45$} & $-1.52]$ \\
\hline Mental illness diagnosed & 1.59 & {$[0.70$} & 2.51] & 2.11 & {$[0.49$} & 3.83] \\
\hline \multicolumn{7}{|l|}{ Power } \\
\hline Age & 0.11 & {$[0.05$} & 0.17] & 0.04 & {$[-0.06$} & $0.14]$ \\
\hline Educational level & 0.38 & {$[-0.66$} & $1.42]$ & -1.05 & {$[-2.92$} & $0.73]$ \\
\hline \multicolumn{7}{|c|}{ Objective measure of incapacity } \\
\hline $\begin{array}{l}\text { Evaluation of incapacity to } \\
\text { work }\end{array}$ & & & & 0.11 & {$[0.07$} & 0.15] \\
\hline Intercept & -6.85 & {$[-10.01$} & $-3.85]$ & -6.70 & {$[-10.78$} & $-2.73]$ \\
\hline $\mathrm{N}$ & & 85 & & & 85 & \\
\hline
\end{tabular}


TABLE 4: Results sub-group analysis - Immigrants only

\begin{tabular}{|c|c|c|c|c|c|c|}
\hline & \multicolumn{3}{|c|}{$\begin{array}{l}\text { Model } 5 \\
\text { Duration }\end{array}$} & \multicolumn{3}{|c|}{$\begin{array}{c}\text { Model } 6 \\
\text { Allocation }\end{array}$} \\
\hline & Mean & $10 \%$ & $90 \%$ & Mean & $10 \%$ & $90 \%$ \\
\hline \multicolumn{7}{|l|}{ Deservingness } \\
\hline \multicolumn{7}{|l|}{ Ethnic group ${ }^{\mathrm{a}}$} \\
\hline Turkey & -119.78 & {$[-668.10$} & 431.99] & 1.99 & {$[-1.04$} & $5.28]$ \\
\hline Mental illness diagnosed & -264.16 & {$[-627.95$} & 102.22] & 3.01 & {$[1.22$} & 5.04] \\
\hline \multicolumn{7}{|l|}{ Power } \\
\hline Age & 24.69 & {$[-1.23$} & 50.54] & -0.03 & {$[-0.18$} & $0.11]$ \\
\hline Educational level & -401.29 & {$[-746.23$} & $-54.75]$ & -0.77 & {$[-2.65$} & 1.00] \\
\hline \multicolumn{7}{|l|}{ Group-specific measures } \\
\hline Years having lived in $\mathrm{CH}$ & -40.18 & {$[-62.52$} & $-17.71]$ & 0.23 & {$[0.09$} & $0.41]$ \\
\hline Intercept & 2225.44 & {$[1351.81$} & 3107.72] & -7.68 & {$[-11.96$} & $-3.49]$ \\
\hline $\mathrm{N}$ & & 34 & & & 34 & \\
\hline
\end{tabular}

Note: ${ }^{\text {a }}$ reference category Swiss; mean posterior distributions of linear and logistic Bayesian regression coefficients and 90 percent credibility intervals (in squared brackets).

Bold: relevant coefficients. 
TABLE 5: Descriptive analysis - Subjective perceptions of IV officers and medical experts

\begin{tabular}{|c|c|c|c|}
\hline & $\begin{array}{c}\text { Swiss } \\
(\mathrm{N}=48)\end{array}$ & $\begin{array}{c}\text { Former- } \\
\text { Yugoslavian } \\
(\mathrm{N}=32)\end{array}$ & $\begin{array}{l}\text { Turkish } \\
(\mathrm{N}=10)\end{array}$ \\
\hline \multicolumn{4}{|l|}{ Credibility of symptoms and general suspicion } \\
\hline $\begin{array}{l}\text { (1) \% of cases no verifiable source of physical pain } \\
\text { symptoms was detected }\end{array}$ & $53.33 \%{ }^{\mathrm{bc}}$ & $93.75 \%^{\mathrm{a}}$ & $100 \%^{\mathrm{a}}$ \\
\hline $\begin{array}{l}\text { (2) \% of cases no verifiable source of mental (stress) } \\
\text { symptoms was detected }\end{array}$ & $23.81 \%^{\mathrm{b}}$ & $50.00 \%{ }^{\mathrm{a}}$ & $50.00 \%$ \\
\hline (3) \% of cases IV officer or expert suspect simulation & $0.00 \%{ }^{\mathrm{bc}}$ & $30.00 \%{ }^{\mathrm{a}}$ & $37.50 \%{ }^{\mathrm{a}}$ \\
\hline \multicolumn{4}{|l|}{ Complexity of procedure } \\
\hline (4) Avg. number of doctors consulted & $2.02^{\mathrm{b}}$ & $3.31^{\mathrm{a}}$ & 2.6 \\
\hline (5) Avg. number of file documents & $38.94^{\mathrm{b}}$ & $57.43^{\mathrm{a}}$ & 43.00 \\
\hline \multicolumn{4}{|l|}{ Contentiousness of procedure } \\
\hline (6) \% of cases lawyer was involved & $14.58 \%{ }^{\mathrm{bc}}$ & $70.96 \%{ }^{\mathrm{a}}$ & $50.00 \%{ }^{\mathrm{a}}$ \\
\hline (7) \% of cases complaints or objections were mentioned & $25.00 \%^{\mathrm{b}}$ & $53.13 \%^{\mathrm{a}}$ & $40.00 \%$ \\
\hline $\begin{array}{l}\text { (8) \% of cases disagreement between experts on health } \\
\text { status was encountered }\end{array}$ & $20.45 \%{ }^{\mathrm{b}}$ & $48.15 \%^{\mathrm{a}}$ & $40.00 \%$ \\
\hline $\begin{array}{l}\text { (9) \% of cases disagreement between experts on work } \\
\text { capacity was encountered }\end{array}$ & $57.78 \%$ & $71.88 \%$ & $60.00 \%$ \\
\hline $\begin{array}{l}\text { (10) \% of cases disagreement on work capacity between } \\
\text { applicant and IV officer were encountered }\end{array}$ & $12.50 \%^{\mathrm{c}}$ & $33.33 \%$ & $66.66 \%^{\mathrm{a}}$ \\
\hline
\end{tabular}

Note: ${ }^{\text {a }}$ significant difference to native Swiss group; ${ }^{\mathrm{b}}$ significant difference to Yugoslavian group; ${ }^{\mathrm{c}}$ significant difference to Turkish group. Group-comparisons/significance tests based on Sidak test statistics. 
FIGURE 1: Social construction - Results from cluster analysis

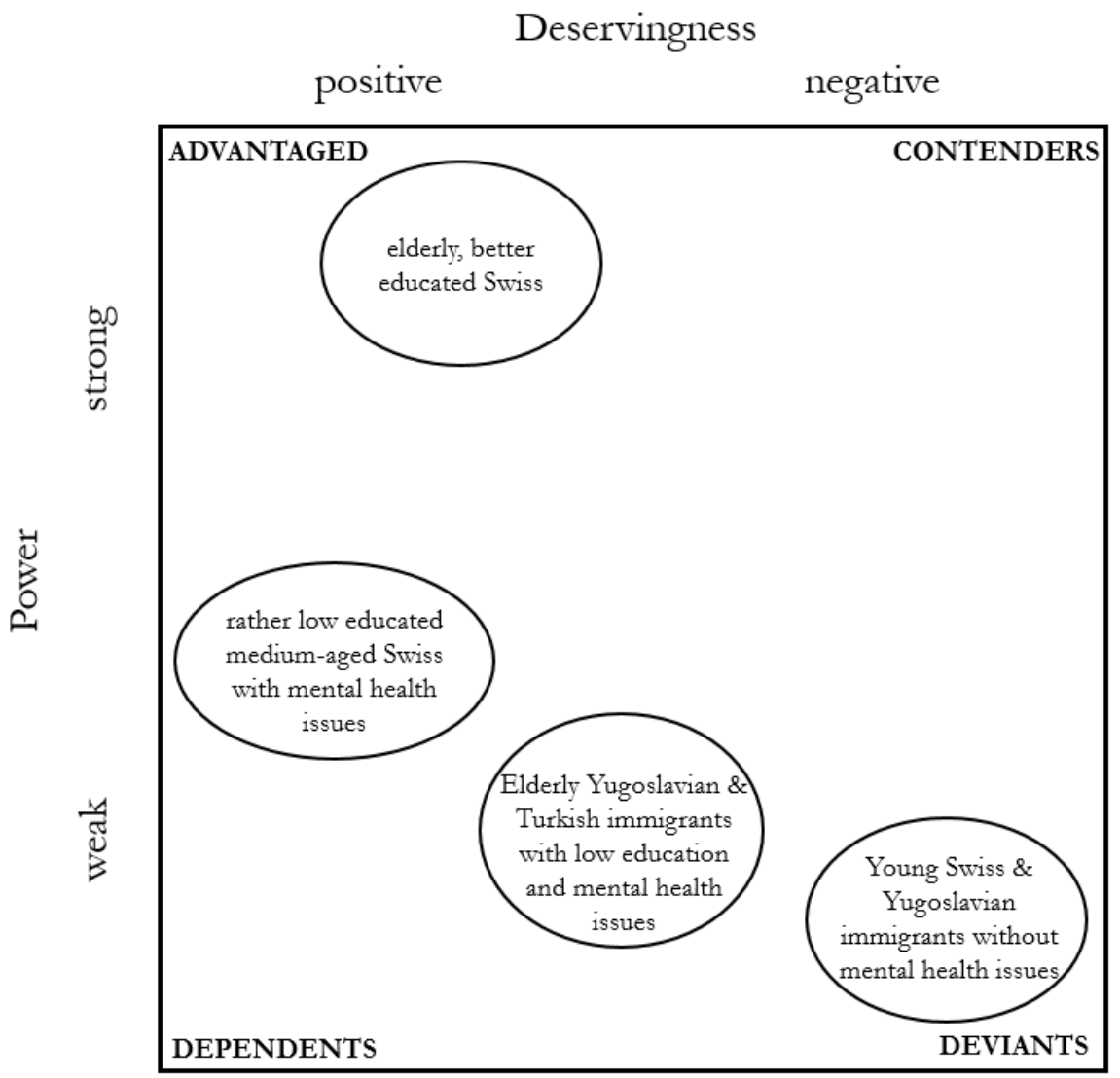

Note: Approximated positions of clusters. 


\section{Appendix}

TABLE A1: Variables, operationalization and descriptive statistics

\begin{tabular}{|c|c|c|}
\hline Variable & Stats & Operationalization \\
\hline \multicolumn{3}{|l|}{ Outcome variables } \\
\hline Duration of procedure & $\begin{array}{l}\text { Min=44 } \\
\text { Max=2516 } \\
\text { Mean=1267.23 } \\
\text { Sd=777.02 }\end{array}$ & $\begin{array}{l}\text { Days from the start to the end of the } \\
\text { application procedure, i.e. final decision } \\
\text { taken. Ongoing applications were coded } \\
\text { with the maximum number of days. }\end{array}$ \\
\hline Evaluation of invalidity & $\begin{array}{l}\operatorname{Min}=0 \\
\operatorname{Max}=100 \\
\text { Mean=45.78 } \\
\text { Sd=36.47 }\end{array}$ & $\begin{array}{l}\text { Evaluation of IV office of applicant's } \\
\text { capacity to work at end of procedure / } \\
\text { after } 4 \text { years. Measured as difference } \\
\text { between validity income and earned } \\
\text { income considering health damage and } \\
\text { reintegration efforts, in \% of validity } \\
\text { income. High values indicate high } \\
\text { incapacity to work. }\end{array}$ \\
\hline $\begin{array}{l}\text { Receiving partial or full } \\
\text { pension }\end{array}$ & $\begin{array}{l}\operatorname{Min}=0 \\
\operatorname{Max}=1 \\
\text { Mean=0.39 } \\
\text { Sd=0.49 }\end{array}$ & $\begin{array}{l}\text { Entitlement of invalidity pension after } \\
\text { decision was taken. } \\
0=\text { receiving no pension } \\
1=\text { receiving partial or full pension }\end{array}$ \\
\hline Influence variables & & See table 1, 2, and 3 \\
\hline Nationality & $\begin{array}{l}\text { Swiss }=51.16 \% \\
\text { Former Yugoslavia=37.21 } \\
\text { Turkish }=11.63 \%\end{array}$ & $\begin{array}{l}1=\text { Swiss } \\
2=\text { Ex-Yugoslavia } \\
3=\text { Turkey }\end{array}$ \\
\hline Age & $\begin{array}{l}\operatorname{Min}=35 \\
\operatorname{Max}=59 \\
\operatorname{Mean}=48.48 \\
\text { Sd=6.88 }\end{array}$ & Age in years \\
\hline Educational level & $\begin{array}{l}\text { Low education }=46.67 \% \\
\text { Medium education }=53.33 \%\end{array}$ & $\begin{array}{l}1=\text { low education } \\
2=\text { =medium level education }\end{array}$ \\
\hline Mental health issues & $\begin{array}{l}\text { Yes }=45.35 \% \\
\text { No }=54.65 \%\end{array}$ & $\begin{array}{l}\text { Mental health issues were diagnosed at } \\
\text { the beginning of the procedure. } \\
0=\text { no mental health issue } \\
1=\text { mental health issue }\end{array}$ \\
\hline Ethnic group & $\begin{array}{l}\text { Immigrant }=50 \% \\
\text { Native }=50 \%\end{array}$ & $\begin{array}{l}0=\text { immigrant } \\
1=\text { native Swiss }\end{array}$ \\
\hline Evaluation of invalidity & $\begin{array}{l}\text { Min }=0 \\
\operatorname{Max}=100 \\
\text { Mean=45.78 } \\
\text { Sd=36.47 }\end{array}$ & $\begin{array}{l}\text { Evaluation of IV office of applicant's } \\
\text { capacity to work at end of procedure / } \\
\text { after } 4 \text { years. Measured as difference } \\
\text { between validity income and earned } \\
\text { income considering health damage and } \\
\text { reintegration efforts, in \% of validity } \\
\text { income. High values indicate high } \\
\text { incapacity to work. }\end{array}$ \\
\hline $\begin{array}{l}\text { Disagreement on health status } \\
\text { or work capacity between } \\
\text { experts }\end{array}$ & $\begin{array}{l}\text { Yes }=63.33 \% \\
\text { No=36.67\% }\end{array}$ & $\begin{array}{l}\text { Disagreement on health condition or } \\
\text { disagreement on incapacity to work. } \\
0=\text { no disagreement } \\
1=\text { disagreement on health or incapacity }\end{array}$ \\
\hline Integration in Switzerland & $\begin{array}{l}\text { Min }=0 \\
\text { Max }=100 \\
\text { Mean=45.78 } \\
\text { Sd=36.47 }\end{array}$ & $\begin{array}{l}\text { Years the applicant has been living in } \\
\text { Switzerland (only immigrants) }\end{array}$ \\
\hline
\end{tabular}




\begin{tabular}{|c|c|c|}
\hline Variable & Stats & Operationalization \\
\hline Number of doctors consulted & $\begin{array}{l}\operatorname{Min}=0 \\
\operatorname{Max}=7 \\
\text { Mean= } 2.54 \\
\text { Sd=1.62 }\end{array}$ & Number of doctors consulted \\
\hline $\begin{array}{l}\text { Number of documents in } \\
\text { applicant file }\end{array}$ & $\begin{array}{l}\operatorname{Min}=8 \\
\operatorname{Max}=147 \\
\text { Mean }=45.97 \\
S d=23.93\end{array}$ & Number of documents in applicant file \\
\hline Lawyer & $\begin{array}{l}\text { Yes }=38.20 \% \\
\text { No }=61.80 \%\end{array}$ & $\begin{array}{l}\text { Lawyer was involved } \\
0=\text { no } \\
1=\text { yes }\end{array}$ \\
\hline $\begin{array}{l}\text { Applicant issued complaint or } \\
\text { objection at court }\end{array}$ & $\begin{array}{l}\text { Yes }=36.67 \% \\
\text { No=63.33\% }\end{array}$ & $\begin{array}{l}\text { Applicant issued complaint or objection } \\
\text { at court } \\
0=\text { no } \\
1=\text { yes }\end{array}$ \\
\hline $\begin{array}{l}\text { No verifiable source of } \\
\text { mental (stress) symptoms }\end{array}$ & $\begin{array}{l}\text { Yes }=35.90 \% \\
\text { No }=64.10 \%\end{array}$ & $\begin{array}{l}\text { Perception that applicant has somatoform } \\
\text { stress disorder } \\
0=\text { no } \\
1=\text { yes }\end{array}$ \\
\hline No verifiable pain & $\begin{array}{l}\text { Yes }=73.26 \% \\
\text { No }=26.74 \%\end{array}$ & $\begin{array}{l}\text { Applicant experiences pain symptoms } \\
\text { that do not seem to have a clearly } \\
\text { verifiable physical cause } \\
0=\text { no } \\
1=\text { yes }\end{array}$ \\
\hline Suspicion of simulation & $\begin{array}{l}\text { Yes }=13.95 \% \\
\text { No=86.05\% }\end{array}$ & $\begin{array}{l}\text { Insurance employees suspect that } \\
\text { applicant simulates or exaggerates } \\
\text { symptoms } \\
0=\text { no } \\
1=\text { yes }\end{array}$ \\
\hline $\begin{array}{l}\text { Disagreement on health status } \\
\text { between experts }\end{array}$ & $\begin{array}{l}\text { Yes }=32.10 \% \\
\text { No }=67.90 \%\end{array}$ & $\begin{array}{l}\text { Disagreement on health status between } \\
\text { experts } \\
0=\text { no } \\
1=\text { yes }\end{array}$ \\
\hline $\begin{array}{l}\text { Disagreement on work } \\
\text { capacity between experts }\end{array}$ & $\begin{array}{l}\text { Yes }=63.22 \% \\
\text { No }=36.76 \%\end{array}$ & $\begin{array}{l}\text { Disagreement on work capacity between } \\
\text { experts } \\
0=\text { no } \\
1=\text { yes }\end{array}$ \\
\hline $\begin{array}{l}\text { Discrepancy in self- } \\
\text { assessment and objective } \\
\text { assessment of capacity to } \\
\text { work }\end{array}$ & $\begin{array}{l}\text { Yes }=24.66 \% \\
\text { No }=75.34 \%\end{array}$ & $\begin{array}{l}\text { Applicant's assessment of own capacity } \\
\text { to work differs from assessment by } \\
\text { medical experts or insurance employees } \\
0=\text { no } \\
1=\text { yes }\end{array}$ \\
\hline
\end{tabular}


TABLE A2: Influences on disagreement between medical experts

\begin{tabular}{lccc}
\hline & \multicolumn{3}{c}{ Disagreement } \\
\hline $\begin{array}{l}\text { Deservingness } \\
\text { Nationality }\end{array} \quad$ Mean & $10 \%$ & $90 \%$ \\
$\quad$ former Yugoslavia & & & \\
$\quad$ Turkey & $\mathbf{1 . 1 7}$ & {$[\mathbf{0 . 2 7}$} & $\mathbf{2 . 1 1}]$ \\
Mental illness diagnosed & 0.62 & {$[-0.73$} & $2.02]$ \\
Power & 0.65 & {$[-0.17$} & $1.47]$ \\
Age & & & \\
Educational level & 0.05 & {$[-0.01$} & $0.10]$ \\
Intercept & 0.18 & {$[-0.77$} & $1.15]$ \\
$\mathrm{N}$ & -2.66 & {$[-5.39$} & $-0.04]$ \\
\end{tabular}

Note: ${ }^{a}$ reference category Swiss; mean posterior distributions of linear and logistic Bayesian regression coefficients and 90 percent credibility intervals (in squared brackets); both models were calculated in Stata version 14.2 (bayesmh) using Markov Chain Monte Carlo (MCMC) estimation (20,000 iterations, burn-in 5,000, informative priors for coefficients and (informative) gamma priors for variance components); no signs of nonconvergence were detected; good acceptance rate and efficiency.

Bold: relevant coefficients. 
TABLE A3: Overview over group differences between Swiss citizens and immigrants (former Yugoslavian and Turkish combined)

\begin{tabular}{lccc}
\hline & Swiss citizen & immigrant & p-value \\
\hline Education & 1.70 & 1.33 & $0.00^{*}$ \\
\hline income in CHF & 3993 & 4230 & 0.46 \\
\hline evaluation of integration into Swiss society & 0.82 & 0.66 & 0.11 \\
\hline having had problems with the law & 0.35 & 0.24 & 0.24 \\
\hline drug addiction/alcohol problem & 0.38 & 0.24 & 0.21 \\
\hline marital status & 2.25 & 2.05 & 0.11 \\
\hline
\end{tabular}


TABLE A4: Standard regression results

\begin{tabular}{|c|c|c|c|}
\hline & $\begin{array}{c}\text { Model } 1 \\
\text { Duration of } \\
\text { procedure }\end{array}$ & $\begin{array}{c}\text { Model } 2 \\
\text { Evaluation of } \\
\text { incapacity to work }\end{array}$ & $\begin{array}{c}\text { Model } 3 \\
\text { Allocation of } \\
\text { disability } \\
\text { benefit }\end{array}$ \\
\hline \multicolumn{4}{|l|}{ Deservingness } \\
\hline \multicolumn{4}{|l|}{ Nationality $^{\mathrm{a}}$} \\
\hline \multirow[t]{2}{*}{ former Yugoslavia } & $388.27^{* *}$ & -2.99 & -1.14 \\
\hline & (164.19) & $(8.11)$ & $(1.19)$ \\
\hline \multirow[t]{2}{*}{ Turkey } & 51.76 & -10.84 & $-3.87^{*}$ \\
\hline & $(259.67)$ & $(13.13)$ & $(2.03)$ \\
\hline \multirow[t]{2}{*}{ Mental illness diagnosed } & -100.28 & $17.99^{* *}$ & $1.83^{*}$ \\
\hline & $(144.10)$ & (7.27) & (1.01) \\
\hline \multicolumn{4}{|l|}{ Powerfulness } \\
\hline \multirow[t]{2}{*}{ Age } & $-23.36^{* *}$ & $1.68^{* * *}$ & 0.06 \\
\hline & (11.17) & $(0.56)$ & $(0.08)$ \\
\hline \multirow[t]{2}{*}{ Educational level } & $-446.40^{* *}$ & 7.19 & -1.03 \\
\hline & (169.66) & $(8.69)$ & $(1.21)$ \\
\hline \multicolumn{4}{|l|}{ Procedure specific influence } \\
\hline \multirow[t]{2}{*}{ disagreement on health status } & $215.99^{* *}$ & & \\
\hline & $(92.02)$ & & \\
\hline \multirow[t]{2}{*}{ Evaluation of incapacity to work } & & & $0.09^{* * *}$ \\
\hline & & & $(0.02)$ \\
\hline \multirow[t]{2}{*}{ Intercept } & $2822.36^{* * *}$ & $-51.81^{*}$ & $-6.62^{*}$ \\
\hline & $(548.57)$ & $(27.90)$ & $(3.90)$ \\
\hline $\mathrm{N}$ & 86 & 85 & 85 \\
\hline
\end{tabular}

Standard errors in parentheses; ${ }^{*} p<.10,{ }^{* *} p<.05,{ }^{* * *} p<.01$; linear regression methods were implemented for both duration of the procedure and evaluation of the incapacity to work models, logistic regressions were used for allocation of disability benefit model. 